\title{
Cserszegtomaj területhasználatának vizsgálata geoinformatikai módszerekkel
}

\section{Morva Tamás}

egyetemi hallgató, PTE TTK, E-mail: morvatamas@gmail.com

\section{Kulcsszavak}

területhasználat

geoinformatika

hegyközség

Cserszegtomaj
DOI: 10.17799/2014.1.27

\begin{abstract}
Absztrakt
Munkámban a Keszthelyi-hegység hegylábfelszinén elhelyezkedö Cserszegtomaj nyugati részének területhasználati elemzését végeztem el. A területre a Keszthelyt körülölelő szölőhegyek természetföldrajzi és tájhasználati sajátosságai jellemzöek. Ebben a dolgozatban a területhasználat változását mutatom be, történeti földrajzi és geoinformatikai módszerek felhasználásával. Egy jellegzetes $8 \mathrm{~km}^{2}$-es területet választottam ki, amit három idökeresztmetszetben vizsgáltam meg. A második katonai felmérés, az 1985-89-es topográfia térkép és a 2005-ben készült légifelvétel idöben másfél évszázadot ölelnek fel. Egy hosszabb és egy rövidebb időszak elemzését teszik lehetővé, amelyek közül az utóbbi a rendszerváltás utáni gyors változásokat szemlélteti. A térképi adatok feldolgozása mellett összehasonlítottam ezeket az írott történeti forrásokkal. Magassági övezeteket jelöltem ki, majd megnéztem az egyes felszínboritottság típusok változásait a vizsgát terület egészén, illetve ezekben az övezetekben külön-külön. Összefüggéseket kerestem a történelmi, gazdasági és területhasználati jellemzők között. Megállapitottam, hogy a legalacsonyabb, legkisebb lejtésü részeket mind a mai napig szántóföldek boritják, bár ezek aránya csökkent a 19. század közepe óta. A közepes magasságú és meredekségü területeken eredetileg vegyes volt a felszínhasználat, de az utóbbi idöben a szölök és rétek erös csökkenése, valamint a beépített területek és kertek erös növekedése figyelhetö meg itt. A vizsgált terület legstabilabb területhasználati formáját a legmagasabb térszineket boritó erdők adják.
\end{abstract}

\section{Bevezetés és célkitúzés}

Az elmúlt évszázadokban a települések helyválasztását és életét hazánkban is jelentős mértékben befolyásolták a természeti adottságok. Számos kutató foglalkozott már egy-egy település, vagy kisebb-nagyobb téregység vizsgálata során ezekkel a kérdésekkel (Beluszky, 1999; Elekes, 2008; Frisnyák, 1990; Gyenizse, 2001a, 2001b, 2005; Gyenizse \& Kovács, 1999, 2000; Gyenizse, Lovász, \& Tóth, 2011; Hajnal, Pirisi, \& Trócsányi, 2009; Lovász, 1982; Marosi \& Szilárd, 1974; Mendöl, 1963; Mohos, 1988; Pécsi, 1984; Perényi, 1975; Tóth, 1981; Wilhelm, 1997). A kiválasztott $8 \mathrm{~km}^{2}$-es terület véleményem szerint a település legjellegzetesebb része és jól tükrözi az ott lezajló változásokat.

Cserszegtomaj hegyközség képét évszázadokon keresztül a mezőgazdasági müvelés sajátosságai határozták meg és ez a település mai állapotára is hatással van. A gazdálkodást a természeti viszonyok is befolyásolják, a magasság, lejtődőlés és kitettség összefügg a területhasználattal. Ezért szolgálhat ez a tanulmány példaként a domborzatból levezethető információ sokrétű felhasználhatóságára.
A Balaton környékének részletes tanulmányozása id. Lóczy Lajos vezetésével valósult meg 1891-től, melynek összefoglaló kötetét is ő maga írta meg (Lóczy, 1920). A széleskörü kutatások következtében a Balaton és környezete rendkívül alaposan leírt területté vált. 1913-ban jelent meg a Balaton monográfia sorozat földtani kötete, „A Balaton környékének geológiai képzödményei és ezeknek vidékek szerinti telepedése" (Lóczy, 1913). A mü a Keszthelyi-hegység kutatásának is az egyik legfontosabb állomása. A 20. században egyre pontosabb földtani térképek születtek, Bohn Péter 1979-ben új eredményekkel egészítette ki a korábbi ismereteket (Bohn, 1979). 1999ben id. Lóczy Lajos születésének 150. évfordulóján jelent meg a Balaton-felvidékről 1 : 50 000-es méretarányú földtani térkép és hozzá tartozó magyarázó kötet (Budai et al., 1999).

Jelen munka szempontjából azok a történelmi források fontosak, amelyek pontos számszerü adatokat szolgáltatnak a népességről, a területhasználati típusokról, vagy a település egyéb jellemzőiről. Ilyeneket találunk Bontz József „Keszthely város monográfiája” c. müvében (Bontz, 
1896), Benda Gyula hegyközségekkel foglalkozó tanulmányaiban (Benda, 1997) és Vajkai Aurél néprajzkutató munkáiban (Vajkai, 1999).

A számszerủ információk kinyerésére kiváló lehetőséget biztosítanak a geoinformatikai programok (Gyenizse, 2007, 2010; Józsa, 2013; Kovács, Tózsa, \& Gecső, 1988; Nagyváradi \& Pirkhoffer, 2008; Szabó G. \& Szabó S., 2010, 2013; Szabó, 2001). Célom, hogy minél objektívebb módszerrel tárjam fel az elmúlt másfél évszázad területhasználatának változását a vizsgált területen.

A vizsgálat során célom a domborzati modell létrehozása, illetve a különböző időpontokban készült térképekről a felszínborítottság digitalizálása, ezek elemzése geoinformatikai módszerekkel, továbbá az eredmények összevetése a történelmi forrásokkal.

\section{Kutatási módszerek}

A vizsgálathoz másodlagos adatgyüjtéssel szereztem adatokat, azaz a Pécsi Tudományegyetem Természettudományi Kar Földrajzi Intézetének (PTE TTK FI) térképei közül használtam fel a megfelelő szelvényeket. Három térképet hasonlítottam össze. Időben legkorábbi a második katonai felmérés, amely 1855-56-ban készült el a vizsgált területen (1. ábra), majd az 1985-1989 közötti felmérés $1: 10$ 000-es méretarányú topográfiai térkép idevágó szelvénye, végül a 2005-ben készült légi felvételezés ortofotója voltak a vizsgálat alapjai. A vizsgált térképi adatok lehetővé teszik egy hosszabb távú és egy rövidebb távú (rendszerváltás utáni) változás elemzését.

A térképi adatokat ArcGIS szoftverrel dolgoztam fel, a cikk megírásához és a számszerú adatok kiértékeléséhez a Libre Office programcsomagot használtam.

A digitalizálás során a területhasználati kategóriákat a következőképpen osztottam be: erdő; fiatal erdő, bozót; rét, legelő; kert, gyümölcsös; szőlő; szántóföld; beépített terület. Ezek a fiatal erdő, bozót kategóriát kivéve valamennyi térképen viszonylag jól elkülöníthetők. Azért tartottam mégis fontosnak ennek a kategóriának a bevezetését, mert a két utóbbi térképen rendelkezésre áll és információt ad a müvelés alól kivont területek elhelyezkedéséröl. A második katonai felmérés térképe más tekintetben is problémás volt. Itt több objektumtípust is másképpen ábrázoltak, mint a későbbi topográfiai térképen és légi felvételen. Például a topográfiai térképen ábrázolt lakott területeket itt nem találunk, az épületeket közvetlenül kert, szántó stb. övezi, mely utalhat arra, hogy akkoriban az elkerített udvarok még nem voltak jellemzők. Ezen kívül vannak olyan elemek, amelyek csak egy térképen jelennek meg.

A második katonai felmérés szelvényéről 193 darab, az 1985-89-esről 539 darab, a 2005-ösről 708 darab területhasználati poligont digitalizáltam. A digitalizálás munkaigényes, de a pontos eredmények eléréséhez megfelelően alaposan igyekeztem elvégezni.
A domborzatmodellhez szükséges szintvonalakat az 1985-89-es felmérés 1 : 10 000-es topográfiai térképéről digitalizáltam (2. ábra). A domborzatmodell az ArcGIS Topo to Raster algoritmusával készült. Az antropogén hatások miatt a domborzat természetesen nem teljesen állandó (pl. bányászat), de ez a hatás a területen elhanyagolható kiterjedésü. Az 1980-as években a Kö-hát kavicsbányáját már elkezdték müvelni, amely bánya 2005 re már valamivel nagyobb területet foglal el, viszont 1855-56-ban még nyoma sem volt.

Az adatok feldolgozáshoz, megjelenítéséhez és a domborzatmodell elkészítéséhez is ArcGIS-t használtam. A modellből vezettem le a lejtőkitettség és átlagos lejtőhajlás értékeit. Összehasonlítottam az egyes területhasználati formák abszolút, illetve magassági övezetek szerinti megoszlását és változását. A magassági övezeteket 20 méteresre választottam meg, a vizsgált terület teljes magasságprofiljának a figyelembevételével. Ez a beosztás már elég részletes ahhoz, hogy használható eredményeket kapjak.

\section{Cserszegtomaj és környékének természeti környezete}

Cserszegtomaj vidéke az ősidőktől fogva ember által lakott terület volt, mert stratégiailag kedvező helyen terül el. A terület központja az ókorban a római időkben Fenékpuszta, majd a honfoglalás után Keszthely. Eközben a cserszegtomaji terület fejlődését mindvégig a mezőgazdasági jelleg határozta meg. Már a római kortól kezdődően termesztettek szőlőt a környéken. A középkorban Keszthely városa körül jöttek létre az azt övező hegyközségek, melyekben az itt élők elszórtan megtelepedve sajátos gazdálkodást folytattak, de a központi szerepet továbbra is a város töltötte be. A török időkben, a hegyközségekben egyre nehezebbé vált az élet, a végén már állandó lakossággal sem rendelkeztek. A veszély elmúltával ismét fejlődésnek indult a szőlőhegy, amit a lakosság számának, illetve a megművelt területek nagyságának növekedése is mutat (Benda, 1997), de ez igazán csak a 19. századtól vált dinamikussá. A következő korok eseményeit az eredmények részletezésével párhuzamosan tekintem át.

Cserszegtomaj területének nagy része a Keszthelyihegység nyugati hegylábfelszínén fekszik. A Keszthelyi-hegységben az attikai fázistól indulóan több ciklusban történt a kiemelkedés - üledékképződés, aminek eredményeképpen több morfológiai szint alakult ki 300, 250 és 130-165 méteres magasságokban (Bohn, 1979). A hegylábfelszínek a hegység nyugati oldalán a legjobban kifejlődöttek, ahol a vizsgált terület is található. Itt a triász rögök csak helyenként bukkannak a felszínre a fiatalabb üledékek alól. A területen található a 3320 méter összhosszúságú Cserszegtomaji-kútbarlang, mely a temető kútjából nyílik („Cserszegtomaji-kútbarlang” n.d.), míg tőle néhány száz méterrel nyugatra egy 
1. táblázat. A területhasználati formák kiterjedése a vizsgált területen.

\begin{tabular}{|c|c|c|c|c|c|c|}
\hline \multirow{2}{*}{ Terület (ha) } & \multicolumn{2}{|c|}{$1855-56$} & \multicolumn{2}{|c|}{ 1985-89 } & \multicolumn{2}{|c|}{2005} \\
\hline & hektár & $\%$ & hektár & $\%$ & hektár & $\%$ \\
\hline erdő & 239,00 & 29,88 & 219,30 & 27,41 & 243,00 & 30,71 \\
\hline rét, legelő & 18,15 & 2,27 & 71,61 & 8,95 & 32,59 & 4,12 \\
\hline szántóföld & 315,00 & 39,38 & 288,83 & 36,11 & 211,60 & 26,74 \\
\hline kert, gyümölcsös & 50,53 & 6,32 & 58,36 & 7,30 & 143,39 & 18,12 \\
\hline szőlő & 145,49 & 18,19 & 95,28 & 11,91 & 43,64 & 5,52 \\
\hline beépített terület & 8,82 & 1,10 & 66,56 & 8,32 & 117,07 & 14,80 \\
\hline
\end{tabular}

fődolomit kibukkanás, a Biked-tető fekszik, amelyen őshévíz forrástölcsérek ismertek. Rezi környékén homokbányák müködnek.

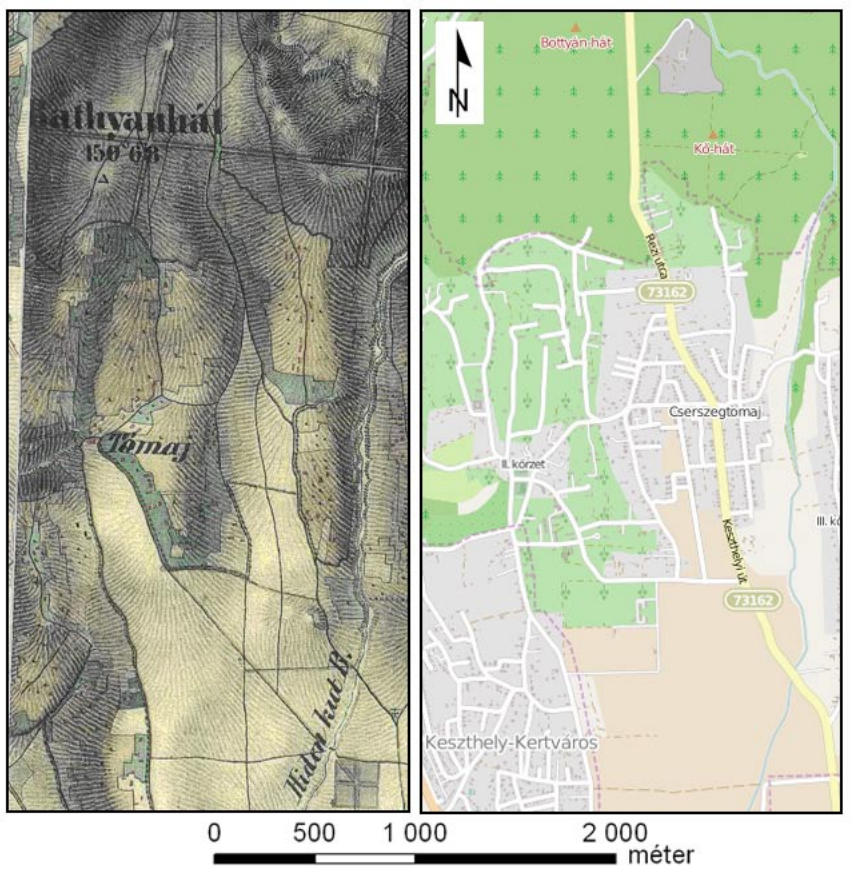

1. ábra: A vizsgált terület a 19. század közepi második katonai felmérés és az Openstreetmap.org jelen állapotokat mutató szelvényén.
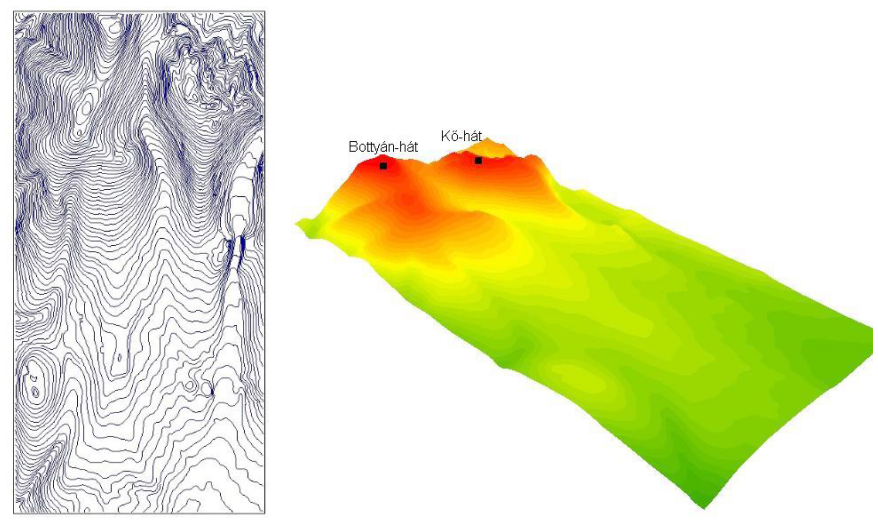

2. ábra: A vizsgált terület digitalizált szintvonalai és a segítségükkel készített domborzati modell délnyugati irányból nézve.
Felszíni vízfolyások a karsztos felszínen nehezen tudnak kialakulni, a vizsgált területen átfolyó Csókakő-patak is csak nagyobb esőzésekkor vagy hóolvadáskor szállít vizet. A vízhiány a hegyközség fejlődésére is nagy hatással volt, mivel csak kevés kút volt ott. Akinek nem volt kútja annak messzire kellett elmennie a vízért, vagy valamilyen ellenszolgáltatás fejében használhatta más kútját. Ez a helyzet a vezetékes vízhálózat kiépítésével változott meg. A vizsgált területen meghatározó délies kitettségü lejtők kedveznek a mezőgazdasági müvelésnek. A talajok kialakulását itt az alapkőzet határozza meg erőteljesen. A tömör kőzeteken rendzina talajok, míg a löszön barnaföldek és agyagbemosódásos barna erdőtalajok képződtek. Ezek a talajok általában vékonyak, vízgazdálkodásuk kedvezötlen, könnyen pusztulnak, amiben közrejátszik a hegylábfelszíneken folytatott mezőgazdasági müvelés.

2. táblázat. A felszínhasználati formák átlagmagassága a vizsgált területen (saját szerk.).

\begin{tabular}{cccc}
\hline Átlagmagasság $\mathbf{( m )}$ & $\mathbf{1 8 5 5}-\mathbf{5 6}$ & $\mathbf{1 9 8 5}-\mathbf{8 9}$ & $\mathbf{2 0 0 5}$ \\
\hline erdö & 201,20 & 231,70 & 200,70 \\
rét, legelö & 180,20 & 196,80 & 188,20 \\
szántóföld & 176,40 & 180,08 & 179,93 \\
kert, gyümölcsös & 185,00 & 192,49 & 193,14 \\
szőlö & 194,47 & 192,31 & 191,71 \\
beépített terület & 192,28 & 192,72 & 195,97 \\
\hline
\end{tabular}

3. táblázat. A felszínhasználati formák átlagos lejtése a vizsgált területen (saját szerk.).

\begin{tabular}{cccc}
\hline Átlagos lejtés (fok) & $\mathbf{1 8 5 5}-\mathbf{5 6}$ & $\mathbf{1 9 8 5}-\mathbf{8 9}$ & $\mathbf{2 0 0 5}$ \\
\hline erdő & 7,06 & 8,50 & 7,60 \\
rét, legelö & 3,69 & 5,71 & 6,33 \\
szántóföld & 3,34 & 3,49 & 3,64 \\
kert, gyümölcsös & 3,57 & 5,18 & 4,76 \\
szőlö & 5,00 & 5,24 & 4,65 \\
beépített terület & 4,28 & 4,66 & 4,63 \\
\hline
\end{tabular}


$1855-56$

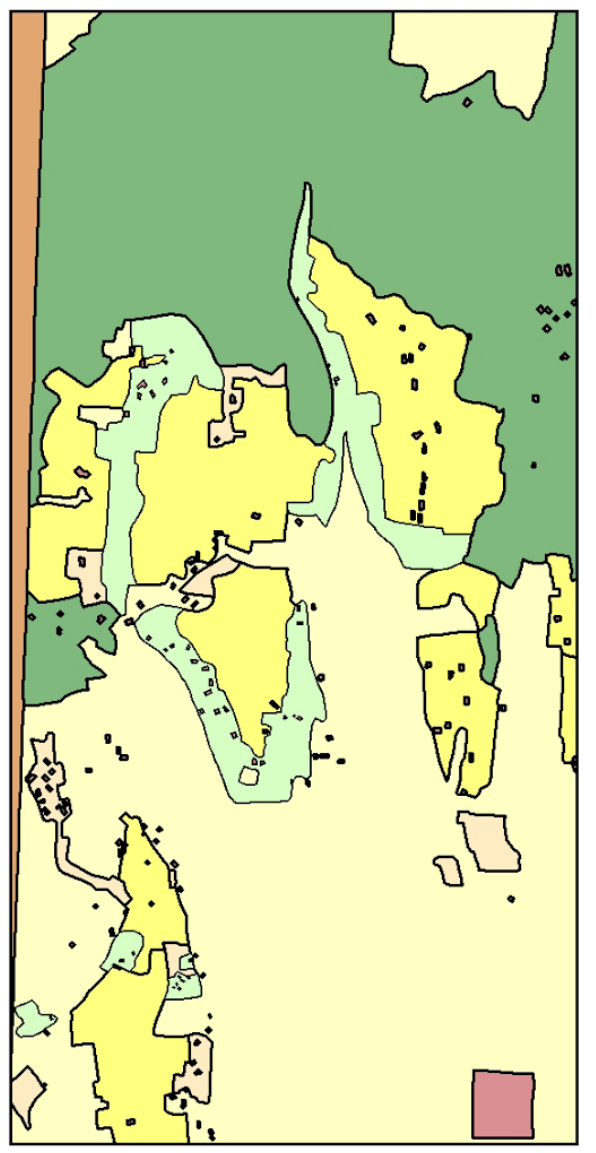

\section{Jelmagyarázat}

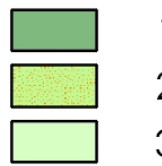

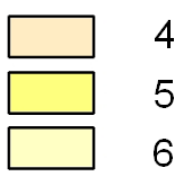

$1985-89$
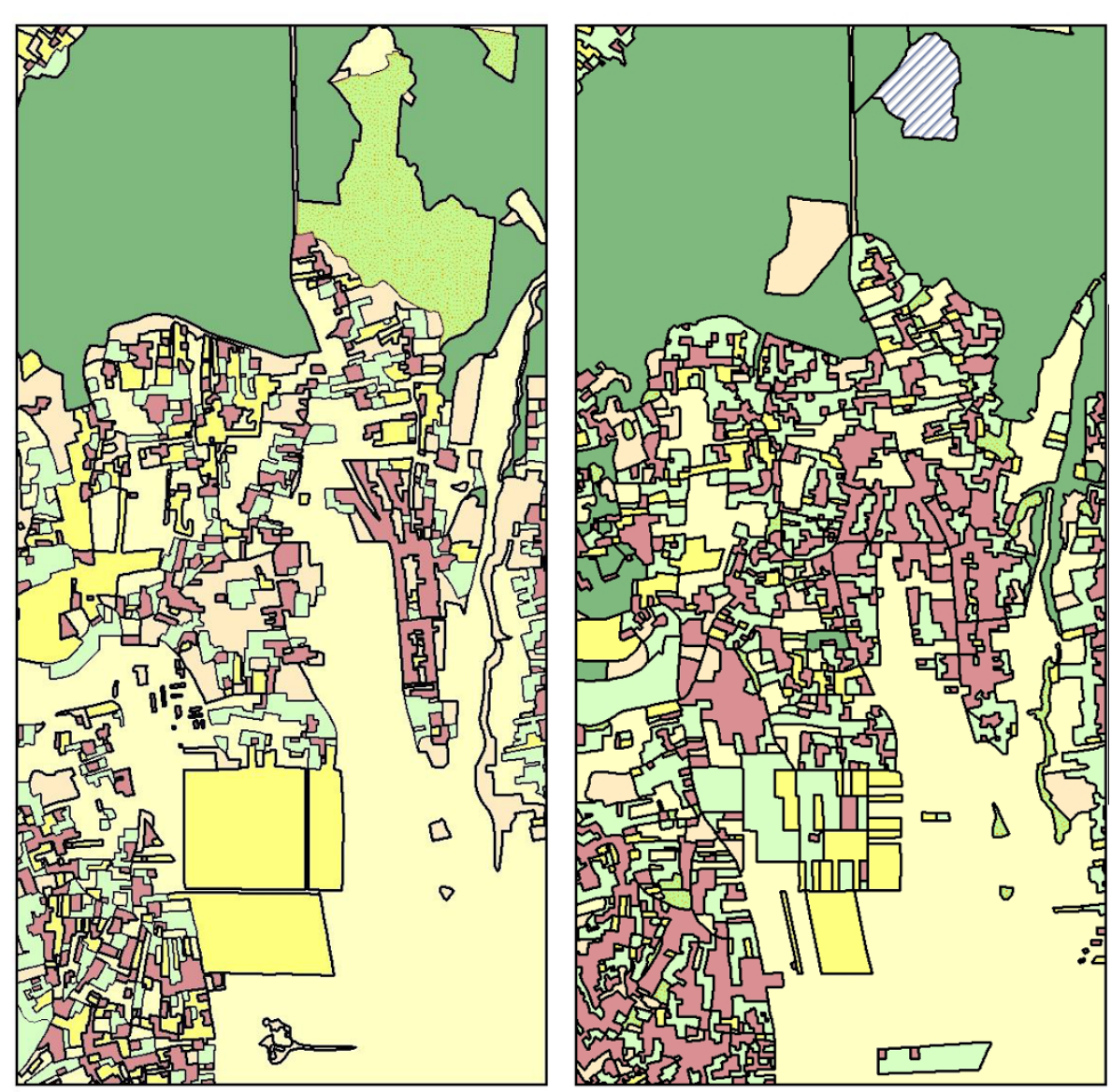

3. ábra: Területhasználat változása 1855 és 2005 között.

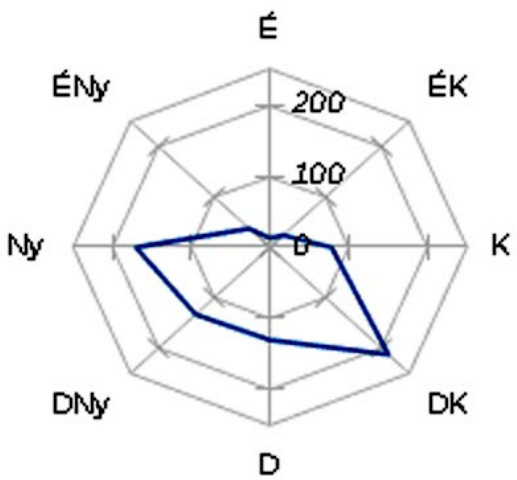

4. ábra: A vizsgált terület kitettségi viszonyainak megoszlása (hektár).

\section{Eredmények}

\subsection{A domborzati modellból kiolvasható ada- tok}

A $8 \mathrm{~km}^{2}$-es terület átlagmagassága a domborzatmodell alapján 206 méter, átlagos lejtőhajlása 5,9 fok. A domborzat délről északra magasodik, a legalacsonyabb pont délen 121 méteres magasságban fekszik, majd legmagasabb pontját, 313,6 métert a Bottyán-háton éri el. A Bottyán-háttól keletre található másik kiemelkedés a Kö-hát, ennek magassága 304 méter. A közöttük húzódó völgy szerepe a közlekedés szempontjából nagyon fontos, mert itt halad a Rezi felé tartó út.

A digitalizált területhasználati formák poligonjaiból és a domborzati modellből rengeteg számszerü adatot olvastam ki. Ezek közül területhasználati formákra vonatkozókat az 1., 2. és 3. táblázatban foglaltam össze, melyekre még hivatkozni fogok később az elemzésben. 

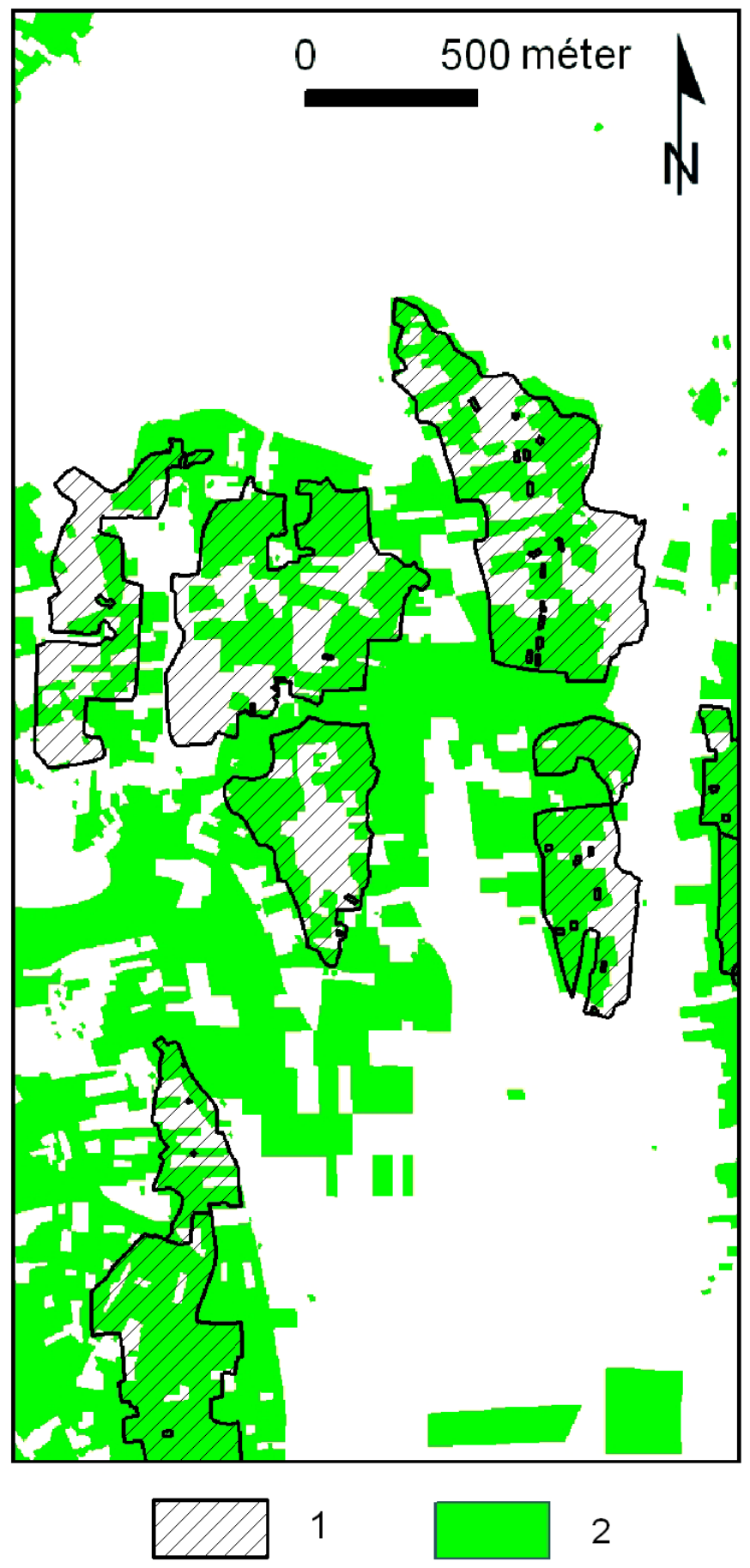

5. ábra: A beépített területek, kertek, gyümölcsösök térnyerése a szôlő́k rovására.

\subsection{Cserszegtomaj élete és területhasználatá- nak változásai az elmúlt másfél évszázadban}

A Keszthely körüli szőlöhegyeken a török uralom után elszórtan telepedtek le az emberek, de néhány sürübben lakott terület is megjelent az utak mellett. Az első épületek ideiglenes hajlékok, pincék, gazdasági épületek voltak (Benda, 1997). A 19. század közepén ezek még szétszórtan helyezkedtek el, de néhol már néhány csoportosulás is megfigyelhető, amelyek már állandóan lakott épületek lehettek (3. ábra). A szőlőhegyek jelentősé- ge a század elejétől egyre növekedett, és a lakosságszám emelkedése szükségessé tette az igazgatás megszervezését. Ez vezetett végül Cserszeg és Tomaj egyesüléséhez (1847), noha a két rész még sokáig elkülönült egymástól a Rezi út mentén.

A vizsgált területen a területhasználat három nagyobb részre osztható már a 19. században. A déli területeken a szántók, az északin az erdők, a középső részeken a szőlők és gyümölcsösök voltak ekkor meghatározóak. A vizsgált terület nagyobb részét mezőgazdaságra, kisebb részét (nagy lejtésủ és rossz talajú területeket) erdőgazdálkodásra hasznosították. Ezzel magyarázható, hogy az 1855-56-os szelvényről digitalizált adatok szerint szántóföldek foglalják el a vizsgált terület kétötödét és erdők az egyharmadát. A harmadik legnagyobb kiterjedéssel a szőlők rendelkeznek, ekkor közel egyötödét borították a vizsgált területnek (3. ábra, 1. táblázat). Ezek többnyire a közepesen lejtősödött domboldalakon foglalnak helyet, ahol nagyon kedvezőek számukra a kitettségi viszonyok, mert nyugati és déli, délkeleti lejtők vannak többségben (4. ábra).

A 19. század végén a szőlők szerepe háttérbe szorult, amiben a filoxéra pusztítása is szerepet játszott. Később sok szőlőt nem telepítettek újra, sőt inkább lassan, de folyamatosan egyre többet kivágtak. Területük a 19. század közepe és 20. század vége között egyharmadával csökkent. A megszünt szőlők helyét csak foltokban hódította vissza a természet, mert ezeket a területeket más módon hasznosították, a legtöbbet beépítették (3. ábra, 1. táblázat).

A 20. század első felében Keszthely és Hévíz a turizmusnak köszönhetően felvirágzott, de ez a hullám Cserszegtomajt egyelöre elkerülte (majd a csak 20. század végén lesz a falu életében jelentősége).

A következő változást a szocializmus hozta, ez jelenti az infrastruktúra fejlesztését és a gazdálkodás, a birtokviszonyok mesterséges átalakítását. Az út és közmühálózat kiépítése tette lehetővé a település növekedését. A mezőgazdaság átalakítása miatt a hagyományos gazdálkodás háttérbe szorult, a fiatalok a városba áramlottak. Az 1980-as évtizedben a korábbihoz képest más települést látunk. Több csomópontot találunk mindkét településrészen, amelyek a korábbi központok helyén vannak (3. ábra). A földművelés gazdasági jelentősége nagyon csökkent, a munkaképes népesség fokozatosan az ipar és a szolgáltató szektorba áramlott (Vajkai, 1999).

A 20. század végén a mezőgazdasági területek aránya azonban továbbra is magas maradt a területen, bár egyre kevesebben „keresték a kenyerüket” ebben az ágazatban. A 19. század közepéhez képest a területi arányok keveset változtak, csak a már említett beépített területek és szőlök változtak jelentősen, illetve az állattenyésztés fellendülése miatt a rétek és legelők területe, amely 2,3\%-ról 9\%-ra emelkedett (1. táblázat).

A második két időbeli metszetünk a rendszerváltás 
utáni változásokat mutatja be. Ekkor a hévízi és keszthelyi turizmus erösödése miatt, Cserszegtomajon is egyre többen (köztük külföldiek is nagy számban) építettek hétvégi házat, nyaralót. A Rezi út mentén lassan összeért a két településrész, mert itt kedvezőek a közlekedési viszonyok és itt jelöltek ki beépítésre szánt területeket (3. $a ́ b r a$ ). Ezen a részen az új állandó lakosok aránya ma is magasabb, mert innen lehet a leggyorsabban a városokba eljutni. A nyugati részen Hévíz közelsége miatt nyaralók épültek. Mivel itt nagyobb a telekméret, ezért a központi részekhez képest kisebb a beépítés sürüsége.

A beépítés növekedése előnyökkel és hátrányokkal is járt. A legfontosabb negatív hatások abból adódnak, hogy a kiépített infrastruktúra nem volt felkészülve nagyobb számú népesség kiszolgálására. Másik megfigyelhető jelenség az volt, hogy egyre sürübben építették be a telkeket, ami miatt az egyes kertek területe egyre kisebb lett, de a kertté átalakított területek kiterjedése nőtt. A kertek arányának növekedését a házak számának növekedéséhez kapcsolhatjuk, mert a településen a legtöbb ház rendelkezik kerttel. Az új beköltözők a hagyományos gazdálkodást már nem folytatják a faluban, az új épületek többsége nem is állandóan lakott.

Megállapítható, hogy a katonai felmérés óta a háttérbe szoruló müvelési ágak közül a szőlök területe csökkent legnagyobb mértékben, területük szétaprózottá vált és helyüket beépített területek és a házak körüli kertek vették át (5. ábra). Számszerüen az eredetileg szőlőként hasznosított területek 62,3\%-át foglalta el a két utóbbi kategória. Szintén a beépítés növekedésének esett áldozatul a rét-legelők és a szántók jelentős része. Ezek a folyamatok egy szerkezetileg átalakuló település képét tárják elénk, ahol ma a régi hegyközségi jelleg bevallottan már csak hagyományként, ha úgy tetszik turisztikai vonzeröként játszik szerepet. 2005-ben az északi részen bányaterület jelenik meg új elemként, területe 8,7 hektár $(1,1 \%)$.

\subsection{A magassági övezetek elemzése}

A vizsgálat következő ,ágát” a domborzat magassági övezeteinek elemzése jelenti, amiből a területhasználati kategóriák magassági eloszlását ismerhetjük meg, illetve ennek változását az utóbbi másfél évszázad során (2. táblázat). A 121 és 313 méteres tengerszint feletti magasságú felszínt 20 méteres övezetekre osztottam. Megfigyelhetö az a tendencia, hogy egyre magasabb térszíneket építenek be.

A legalacsonyabban fekvő területeken, ahol a lejtés is jellemzően kisebb, a szántóföldek vannak többségben. Ez nem csak a természeti adottságok miatt van így. A Keszthely és a szőlőhegyek közötti síkról nem kellett hosszú ideig szállítani a terményt a városig. Ezek a 121140 méteres, a 141-160 méteres és a 161-180 méteres övezetek.

A legnagyobb területü a 161-180 méteres magasságú zóna (213,6 hektár, amely a teljes terület $26,7 \%$-a). Itt a szántóföldek aránya a legmagasabb, azaz 2005-ben 51,7\% volt, de napjainkban is folyamatosan csökken (aránya a 19. század közepén 73,6\% volt). Itt a lakott területek hódítottak teret, föleg a két falurész közötti zónában.

A teljes területen a 181-200 méteres kategória a második legnagyobb, 178 hektár kiterjedésü. Itt a felszín egyre meredekebbé válik, ebből következően eredetileg jelentős volt a szőlőmüvelés. Mára az intenzív beépítés következtében ez háttérbe szorult az épületek és kertek aránya mögött.

A 19. században 201-220 méteren a szőlők foglalták el a legnagyobb területet, de ezt az előzőekhez hasonlóan jórészt beépítették. Ez már egy 7,6 fok átlagos meredekségü övezet (3. táblázat). Kijelenthetö, hogy újabban a meredekebb, kedvezőtlenebb természeti adottságú részeket is beépítik. Ennek hátterében az állhat, hogy ezek jó panorámával rendelkeznek Hévíz és Keszthely irányában. Ebben a magasságban megjelennek az erdők, viszonylag állandó területtel a három vizsgált időszakban.

A következö övezetek egyre meredekebbek, ezért a természetes növényzet nagyobb arányban maradhatott meg, az ember csak a laposabb részeket vette birtokba, de erre is tovább terjeszkedik a település. A legmagasabb, 281300, 301-313 méteres magasságokban szinte kizárólag erdőket találunk.

\section{5. Összefoglalás}

Munkámban Cserszegtomaj térbeli fejlődésének történetét és a tájhasználat változását vizsgáltam a 19. század közepétől a 21. század elejéig. Három térképszelvény állt rendelkezésre az említett időszakban, amelyeket geoinformatikai eszközökkel dolgoztam fel. A számszerű kiértékelés eredményeit folyamatosan összevetettem a településtörténeti eseményekkel.

Cserszegtomaj a Keszthelyt övező szőlöhegyek egyikén alakult ki. A hegyközség a 19. századtól dinamikus fejlődésnek indult, de a szőlőhegyi jelleget csak a század végéig örizte. A lakosság nagy része ekkor még mezögazdaságból élt. A második katonai felmérés ezt az állapotot dokumentálja a két településrész (Cserszeg és Tomaj) egyesülése utáni évtizedben. Ekkor a település területhasználatában a szántók, erdők és szőlők domináltak (3. ábra, 1. táblázat).

A 20. századfordulótól kezdett egyre sokoldalúbb településsé válni, Keszthellyel mindvégig szoros kapcsolatban volt, azonban a város 20 . század elején tapasztalható fellendülés elkerülte. A filoxéra sok szőlőt elpusztított és innentől kezdve ez a gazdálkodási forma folyamatosan háttérbe szorult, ami természetesen a területhasználatban is jól megfigyelhető. A szocialista időszak gazdasági átalakulásait is tükrözi az 1988-89-ben felmért térkép, amelynek jellemzői a nagyobb birtokok, illetve az állattenyésztés előtérbe kerülése és a tervszerü településfejlesztés. A 20. század végéig a szőlőterületek jelentősé- 
gének csökkenése, illetve a rétek és legelök, valamint a beépített területek növekedése figyelhető meg (3. ábra, 1. táblázat).

A rendszerváltástól a nyaraló-pihenő jelleg kerül előtérbe. Ez sok nem állandóan lakott ingatlan felépülésével járt, melyeket nagy számban birtokolnak külföldiek, akik Hévíz és a Balaton közelsége miatt választják Cserszegtomajt. Az új épületek korábban mezőgazdaságilag müvelt területekre, szölőkre, gyümölcsösökre, rétekre épülnek az egyre meredekebb és magasabb domboldalakat is birtokba véve.

A magassági övezetek vizsgálata során arra a következtetésre jutottam, hogy a legalacsonyabb és egyben a legkisebb meredekségü részeket mind a mai napig föleg szántóföldek borítják (bár ezek aránya csökkent a 19 . század közepe óta). A közepes magasságú és meredekségü területeken eredetileg vegyes volt a felszínhasználat, de az utóbbi időben a szőlők és rétek erős csökkenése, valamint a beépített területek és kertek erös növekedése figyelhető meg itt. A vizsgált terület legstabilabb területhasználati formáját a legmagasabb térszíneket borító erdők adják, amelyeket egyelőre a beépítési hullám elkerült.

\section{Irodalomjegyzék}

Beluszky, P. (1999). Magyarország településföldrajza. Általános rész. Budapest-Pécs: Dialóg Campus Kiadó.

Benda, G. (1997). A Keszthely környéki szőlőhegyek építkezése. In Benda G. (szerk.), Társadalomtörténeti tanulmányok (442-455). Budapest: Osiris Kiadó.

Bohn, P. (1979). A Keszthelyi-hegység regionális földta$n a$. Budapest: Müszaki Könyvkiadó.

Bontz, J. (1896). Keszthely város monográfiája. Keszthely: Farkas János könyvnyomdája.

Budai, T., Császár, G., Csillag, G., Dudko, A., Koloszár, L., \& Majoros, G. (1999). A Balaton-felvidék földtana. Budapest: Magyar Állami Földtani Intézet.

Cserszegtomaji kútbarlang. (n.d.). Letöltve: http://www. termeszetvedelem.hu/index.php?pg=cave_4440-2

Elekes, T. (2008). A földrajzi tényezök szerepe a településfejlődésben. Budapest-Pécs: Dialóg Campus Kiadó.

Frisnyák, S. (1990). Magyarország történeti földrajza. Budapest: Tankönyvkiadó.

Gyenizse, P. (2001a). A természeti környezet hatása a DK-Dunántúli településhálózat sürüségének változására. In Judit M. (szerk.), Földrajz az egész világ: Geográfus Doktoranduszok V. Országos Konferenciája (99-104). Miskolc: Miskolci Egyetem.

Gyenizse, P. (2001b). Egy DK-dunántúli példa az eltérő természeti környezettípusok településhálózat sürüségmó- dosító hatására. In Kovács J. \& Lóczy D. (szerk.), A vizek és az ember: Tiszteletkötet Lovász György professzor úr 70. születésnapjára (115-125). Pécs: PTE TTK Földrajzi Intézet.

Gyenizse, P. (2005). Helyi és helyzeti energiák hatása síksági települések fejlődésére (a Dráva-alföld és a Fekete-víz síkja példáján). In Bugya T. \& Wilhelm Z. Tanulmányok Tóth Józsefnek (259-272). Pécs: PTE TTK Földrajzi Intézet.

Gyenizse, P. (2007). A térinformatika néhány alkalmazási lehetősége az önkormányzati irányításban és tervezésben. In Nagyváradi L. \& Varga G. Térinformatika és alkalmazása (62-76). Pécs: PTE TTK Földrajzi Intézet.

Gyenizse, P. (2010). A természeti adottságok szerepe a délkelet-dunántúli települések fejlödésében. Pécs: PTE TTK Földrajzi Intézet.

Gyenizse, P., \& Kovács, B. (1999). A települések és a természeti környezet kapcsolata a Völgységben. In Füleky G. (szerk.), A táj változásai a Kárpát-medencében (331344). Gödöllő: GATE, Szent István Egyetemi Kiadó.

Gyenizse, P., \& Kovács, B. (2000). Természeti környezet és a települések kapcsolata a Drávamenti- síkságon. In Füleky G. (szerk.), A táj változásai a Kárpát-medencében a történelmi események hatására (199-204). Budapest-Gödöllő: GATE, Szent István Egyetemi Kiadó.

Gyenizse, P., Lovász, G., \& Tóth, J. (2011). A magyar településrendszer. A változó természeti környezet és társadalmi-gazdasági viszonyok hatása Magyarország településrendszerére. Geographia Pannonica Nova 10. kötet. Pécs: IDResearch Kft./Publikon.

Gyenizse, P., Nagyváradi, L., \& Pirkhoffer, E. (2008). Pécs domborzati képe, Pécs beépítettsége. Pécsi Szemle 11(2), 97-103.

Hajnal, K., Pirisi, G., \& Trócsányi, A. (2009). A táj és a belőle fejlődő város: Pécs. In Fábián Sz. Á. \& Kovács I. P. (szerk.) Az édesvizi mészkövektöl a sivatagi kérgekig (149-166). Pécs: Publikon Kiadó.

Józsa, E. (2013). A település és a domborzat viszonyának geoinformatikai alapú vizsgálata Bátán. Természetföldrajzi Közlemények a Pécsi Tudományegyetem Földrajzi Intézetéböl, 2013(1), 21-36.

Kovács, Z., Tózsa, I., \& Gecső, O. (1988). A települési környezet információs rendszere (Budapest ökológiai viszonyainak példáján). Városépités, 24(5), 16-18.

Lenner, T. (2012). Győr történeti-településföldrajza. Településföldrajzi tanulmányok, 2012(2), 128-142.

Lóczy, D. (2002). Tájértékelés, földértékelés. BudapestPécs: Dialóg Campus Kiadó.

Lóczy, L. (1913). A Balaton környékének geológiai 
képzödményei és ezeknek vidékek szerinti telepedése. A Balaton tudományos tanulmányozásának eredményei 1. köt., 1. rész, 1. szakasz. Budapest: Kilián.

Lóczy, L. (1920). A Balaton földrajzi és társadalmi eredményeinek leírása: a Balaton tudományos tanulmányozásának eredményei c. monografia-gyüjtemény adatai alapján. Budapest: Hornyánszky Viktor M. Kir. Udvari Könyvnyomdája.

Lovász, Gy. (1982). A természeti környezet szerepe a városépítésben. Településfejlesztés, 2(3-4), 17-26.

Marosi, S., \& Szilárd, J. (1974). Domborzati hatások a gazdálkodásra és településekre. Földrajzi Közlemények, 98, 185-196.

Mendöl, T. (1963). Általános településföldrajz. Budapest: Akadémiai Kiadó.

Mohos, M. (1988). Délnyugat-dunántúli kisvárosok funkcióinak történeti-földrajzi vizsgálata. In Szita L. \& Vonyó J. (szerk.), A dél-dunántúli történészek I. regionális konferenciájának válogatott elöadásai (55-61). Pécs: MTA Pécsi Akadémiai Bizottság.

Morva, T. (2013). Cserszegtomaj kialakulásának geoinformatikai vizsgálata (Kézirat, Szakdolgozat). PTE Földrajzi Intézet, Pécs.

Nagyváradi, L., \& Pirkhoffer, E. (2008). A modern geográfia kihívása: a térinformatika önkormányzati alkalmazásának új lehetőségei Kozármisleny példáján. Földrajzi Értesitö, 57, 299-311.
Pécsi, M. (1984). A földrajzi környezet értelmezése és a környezeti hatások értékelése a gazdaságfejlesztés szolgálatában. Földrajzi Közlemények, 108, 309-313.

Perényi, I. (1975). Városi környezet-városépitészet. Budapest: Akadémiai Kiadó.

Szabó, G., \& Szabó, S. (2010). A Shuttle Radar Topography Mission (SRTM) során nyert adatbázis pontosságának vizsgálata hazai mintaterületeken. Geodézia és Kartográfia, 62(3), 31-35.

Szabó, G., \& Szabó, S. (2013). Városi felszínmodell generálása távérzékelés alapú adatgyüjtéssel. In Lóki J. (szerk.), Az elmélet és a gyakorlat találkozása a térinformatikában, IV. Térinformatika Konferencia és Szakkiállítás, (373-378). Debrecen: Debreceni Egyetem.

Szabó, S. (2001). Connection between Soil and Landscape Sensitivity. Ekológia, 20, 285-291.

Tóth, J. (1981). A településhálózat és a környezet kölcsönhatásának néhány elméleti és gyakorlati kérdése. Földrajzi Értesitő, 30, 267-291.

Vajkai, A. (1999). A magyar nép életmódja. Budapest: Jószöveg Mühely Kiadó.

Wilhelm, Z. (1997). A környezetállapot hatása a településfejlődésre az Alsó-Duna-vidék néhány községében. In Kovács T. (szerk.), A fenntartható mezögazdaságtól a vidékfejlesztésig, IV. Falukonferencia (244-250). Pécs: MTA RKK. 